Thorax (1961), 16, 91.

\title{
THE INHALATION OF PHOSGENE IN A FIRE EXTINGUISHER ACCIDENT
}

\author{
BY \\ R. SEIDELIN \\ From the Royal Air Force Hospital, Nocton Hall
}

(RECEIVED FOR PUBLICATION MAY 6, 1960)

This case report is presented as one of probable inhalation of phosgene, though direct proof is inevitably lacking.

\section{CASE RePort}

A housewife aged 16 was admitted to a Royal Air Force hospital in December, 1958. About 10 hours previously she had been using a carbon tetrachloride extinguisher in fighting a fire which destroyed her caravan home. She had not apparently been exposed to great heat, but had inhaled smoke and fumes which had made her cough at the time. She continued fairly well for the next six hours and then reported to her doctor complaining of a dry cough and some difficulty in breathing. He diagnosed bronchitis, but found her general condition good; however, as her home had been destroyed he requested her admission to hospital.

When she was admitted nearly three hours later her condition had deteriorated considerably: she was extremely breathless, deeply cyanosed, and coughing persistently but ineffectively. Her temperature was $99.2^{\circ} \mathrm{F}$., pulse rate 138 , and respiratory rate 68 per minute. The jugular venous pressure was not raised, and the blood pressure was $110 / 80 \mathrm{~mm}$. $\mathrm{Hg}$, and examination of the chest revealed diminished movement with reduced breath sounds, and widespread wheezing and crepitations. The leucocyte count was 28,000 per c.mm., of which $91 \%$ were polymorphonuclear cells, and a chest radiograph at this time confirmed severe bilateral pulmonary oedema (Fig. 1).

Treatment was started with oxygen by mask and later in an oxygen tent, together with penicillin and a single dose of $1 / 100 \mathrm{gr}$. atropine. Her condition worsened and she lost consciousness: the pulse became irregular and the blood pressure fell to $90 / 60$ $\mathrm{mm}$. Hg. Over the next eight hours the level of consciousness fluctuated and she remained cyanosed; then improvement began with expectoration of small quantities of frothy, very slightly blood-stained sputum.

Next day her condition had improved considerably. The blood pressure had risen to $100 / 80 \mathrm{~mm}$. $\mathrm{Hg}$, the pulse rate remained 130 per min., but the respiratory rate had dropped to 40 per min. While inhaling oxygen there was now little cyanosis. During this day she complained of retrosternal pain on breathing and coughing and a coarse pleuro-pericardial rub was heard, loudest to the left of the sternum. A chest radiograph now showed early mediastinal emphysema.

Improvement was maintained on the third day, when surgical emphysema was noted in the neck. Fig. 2 shows small bilateral pneumothoraces with apical adhesions, increased mediastinal emphysema and subcutaneous emphysema of the neck, with some resolution of the consolidation.

On the fourth day recovery continued, but if oxygen was stopped cyanosis returned. The following day, however, she was able to do without oxygen for short periods, and on the eighth day it was stopped finally. The chest radiograph had by now cleared considerably and the pneumothoraces had resolved (Fig. 3).

Next day the chest appeared normal on clinical examination, though a dry cough was still present. On the thirteenth day she left hospital apparently completely recovered. When seen two months later she had no symptoms, though she admitted that she had been breathless on exertion for two weeks after leaving hospital. Fig. 4 shows almost normal lung fields, though some slight clouding of both apices was noted and the vascular pattern throughout appeared rather heavy. When last seen six months later, perfect health had apparently continued, and she had a normal chest radiograph.

\section{Discussion}

The clinical picture is certainly typical of phosgene poisoning, and although exposure to other fumes and gases, notably oxides of nitrogen, can produce a delayed effect, the circumstances of the fire were such as to make phosgene the most likely agent.

The fire arose from a red-hot coke stove in the small enclosed space of a caravan. The patient endeavoured unsuccessfully for some time to control the blaze with a carbon tetrachloride fire extinguisher. Carbon tetrachloride in a confined space is dangerous for two reasons (Home Office, Fire Service Department, 1943). First, it is almost as effective an anaesthetic as chloroform, and secondly it breaks down in the presence of a hot surface, particularly hot metal, to a variety 


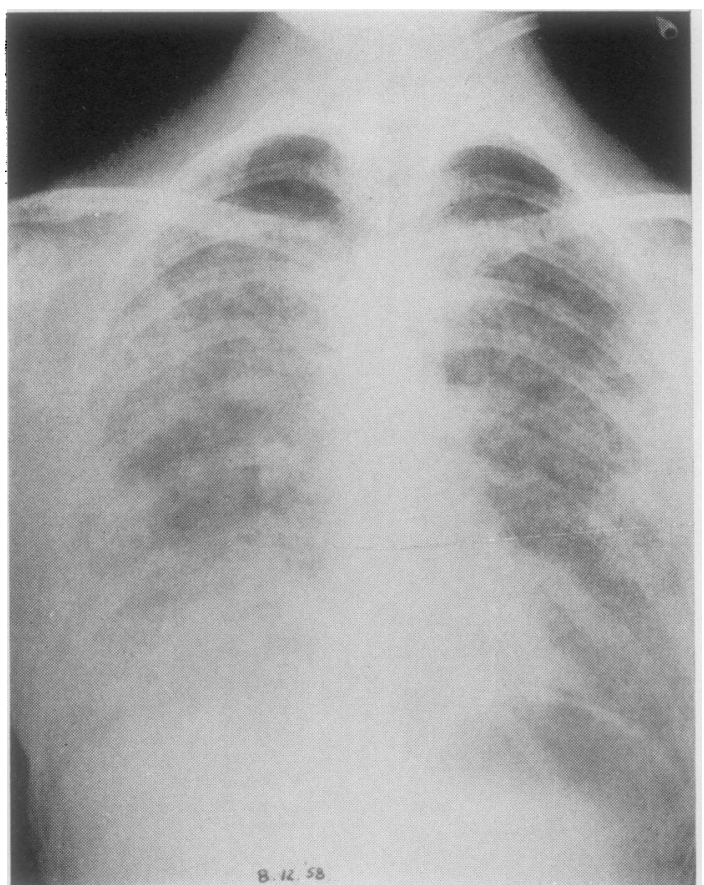

Fig. 1.-Chest radiograph on the first day showing severe bilateral pulmonary oedema.

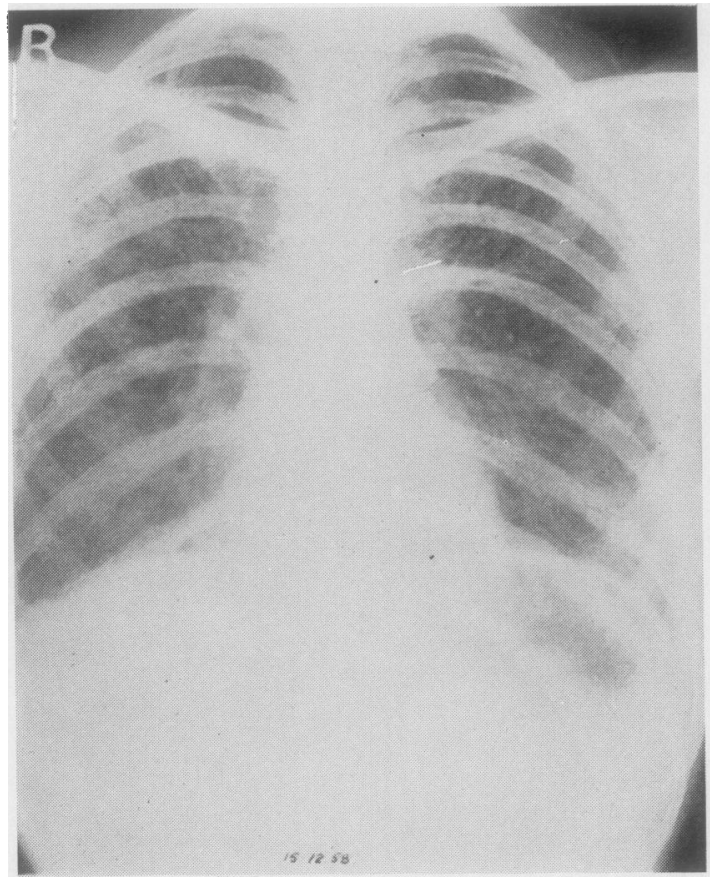

Fig. 3.-Chest radiograph on the eighth day showing considerable resolution. The pneumothoraces had disappeared.

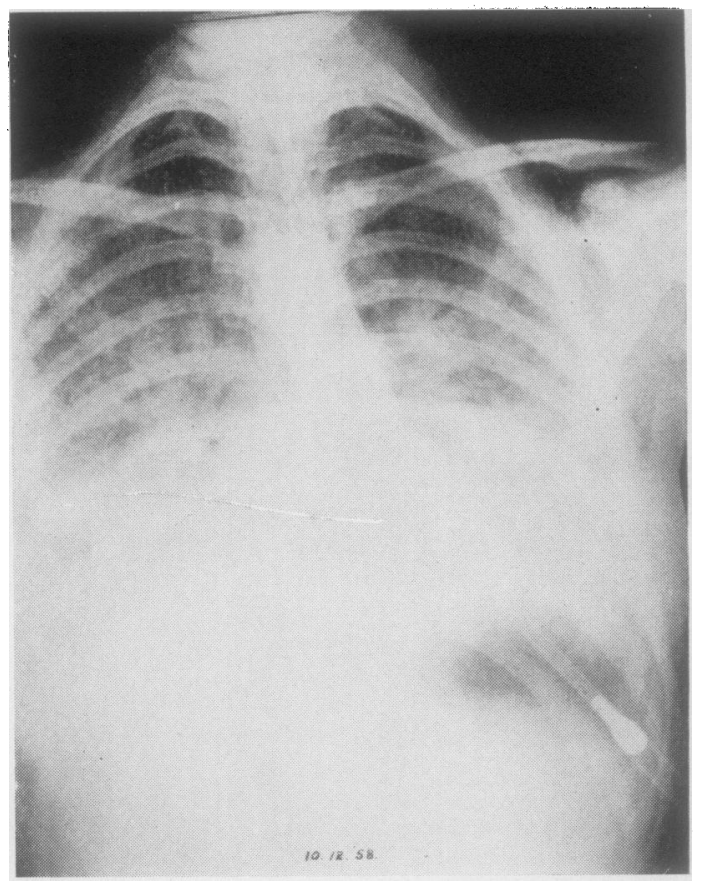

FIG. 2.-Chest radiograph on the third day showing bilateral pneumce thoraces and mediastinal and subcutaneous emphysema. The consolidation is slightly resolving.
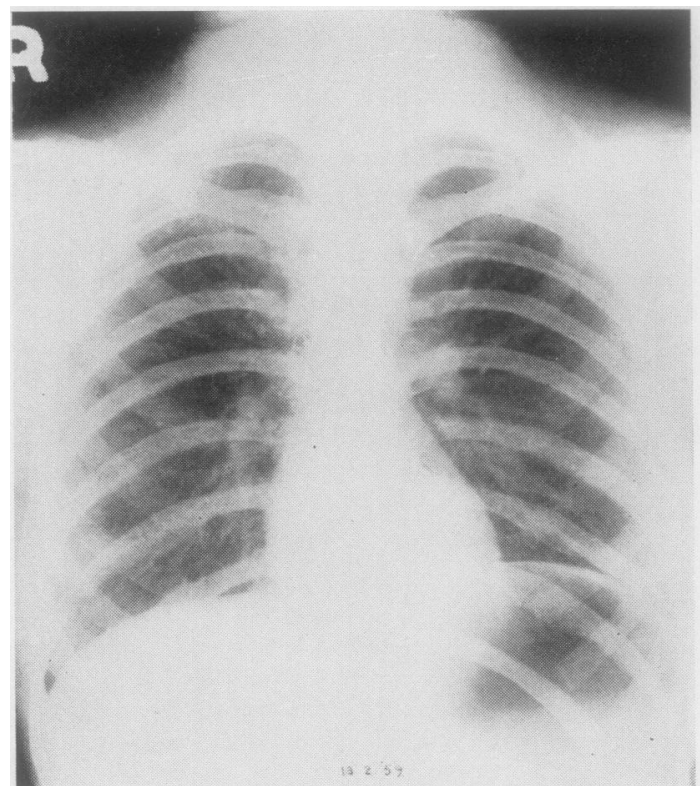

Fig. 4.-Chest radiograph two months later, showing almost normal appearances, slight shadowing at the apices and heavy vascular markings bilaterally. 
of substances, including phosgene (Yant, Olsen, Storch, Littlefield, and Scheflan, 1936; Jones, 1952). The reactions probably involved are these :

$$
\begin{aligned}
& \mathrm{CCl}_{4}=\mathrm{C}+2 \mathrm{Cl}_{2} \\
& 2 \mathrm{C}+\mathrm{O}_{2}=2 \mathrm{CO} \\
& \mathrm{CO}+\mathrm{Cl}_{2}=\mathrm{COCl}_{2} \\
& \text { or directly } \mathrm{CCl}_{4}+\mathrm{H}_{2} \mathrm{O}=\mathrm{COCl}_{2}+2 \mathrm{HCl}
\end{aligned}
$$

The immediate effects of phosgene inhalation are said to include a sweetish "pricking" smell with a desire to cough and vomit (Hegler, 1928). As in this case, heavy smoke inhalation masks this stage by itself causing greater upper respiratory tract irritation. There may be then a period of a few hours of comparative wellbeing, followed by severe breathlessness as pulmonary oedema develops. At first there may be bradycardia which can be inhibited by atropine, but thereafter a varying degree of peripheral vascular failure ensues. Death is due primarily to the interference with oxygen uptake through the oedematous lungs, and most deaths occur within the first 24 hours (Ruge, 1928 ; Blackmore, Christie, Wood, Evans, and Brasher, 1937 ; Steel, 1942 ; Patt, Tobias, Swift, Postel, and Gerard, 1946).

A good deal of experimental work has been done on the pathology of this condition in Great Britain, in Germany, and in the U.S.A. (Wohlwill, 1928 ; Coman, Bruner, Horn, Friedman, Boche, McCarthy, Gibbon, and Schultz, 1947 ; Cameron, 1948). The earliest change is a patchy lobular emphysema with sloughing of bronchiolar mucosa, some bronchioles being plugged and others remaining open: there is some dispute as to whether actual bronchiolar constriction occurs. Soon after this, peribronchial and perivascular oedema are followed by intra-alveolar oedema. If this stage is survived, recovery is usually complete and lung sequelae are rare.
The association of interstitial emphysema and pneumothorax, as in this case, does not appear to have been reported in the literature. It seems likely that it was the result of persistent coughing in the recovery phase, for it was not present on the first day at the height of the pulmonary oedema.

The true frequency of this sort of accident is difficult to determine. In 1951, Spolyar, Harger, Keppler, and Bumsted, reviewing the American literature, reported 15 fatal cases from carbon tetrachloride extinguishers (not only from phosgene poisoning), but hinted that many more deaths occurred and were attributed to so-called "smoke poisoning."

\section{SUMMARY}

An account is given of a patient who suffered from pulmonary oedema after using a carbon tetrachloride fire extinguisher.

The probability is discussed that the illness was caused by inhalation of phosgene.

I am grateful to the Director-General of Medical Services, Royal Air Force, for permission to publish.

\section{REFERENCES}

Blackmore, S., Christie, R. V., Wood, B., Evans, H., and Brasher, C. W. J. (1937). Proc. roy. Soc. Med., 30, 1033.

Cameron, G. R. (1948). Brit. med. J., 1, 965.

Coman, D. R.. Bruner, H. D., Horn, R. C., Friedman, M., Boche, R. D., McCarthy, M. D., Gibbon, M. H., and Schultz, J. (1947). Amer. J. Path., 23, 1037.

Hegler, C. (1928). Dtsch. med. Wschr., 54, 1551.

Jones, A. T. (1952). Proc. roy. Soc. Med., 45, 609.

Home Office, Fire Service Dept. (1943). Manual of Firemanship, 1st ed., Pt 1, p. 153. H.M.S.O., London.

Patt, H. M., Tobias, J. M., Swift, M. N., Postel, S., and Gerard, R. W. (1946). Amer. J. Physiol., 147, 329.

Ruge, H. (1928). Med. Welt, 2, 976.

Spolyar, L. W., Harger, R. N., Keppler, J. F., and Bumsted, H. E. (1951). A.M.A. Arch. industr. Hyg., 4, 156.

Steel, J. P. (1942). Lancet, 1, 316.

Wohlwill, F. (1928). Dtsch. med. Wschr., 54, 1553.

Yant, W. P., Olsen, J. C., Storch, H. H., Littlefield, J. B., and Scheflan, L. (1936). Industr. Engng Chem. (Anal. ed.), 8, 20. 